\title{
Japanese higher education looks to English universities
}

\section{London}

JAPANESE higher education could soon take a firm foothold in England if plans currently being discussed by the universities of Durham and Reading bear fruit.

Durham is hoping to lease a plot of land and buildings to Teikyo University, of Tokyo. The scheme would allow Japanese students to spend time in England, principally to learn English. The leased unit would be a part of Teikyo University and would have no formal links with Durham, institutions would be actively encouraged. Teikyo originally approached Durham through the British Council. Durham was seen as particularly suitable because of its respected School of Oriental Studies and its location in the north-east of England, where the presence of a Nissan carmanufacturing plant has given rise to a sizeable Japanese community. A spokesman for the University of Durham stressed that the scheme is chiefly for the longterm benefits of both the Japanese and British students and staff.

The situation at Reading is very different. The university authorities are talking with an unnamed Japanese party that wants to establish a new university for children of European-based Japanese nationals. It is estimated that in Britain although interaction between the two

alone there are some 22,000 Japanese nationals, including 6,000 children.

Since December 1985, Reading has been under pressure from the University Grants Committee to dispose of a ten-acre site deemed surplus to requirements, and isolated from the university's main 300 -acre campus. The town-centre site contains 35 buildings, including the university's nineteenth century great hall and the microbiology department. The upkeep of the site is posing difficulties for the university, and last June it was offered for sale or lease. It was originally advertised in the United States, but the Japanese showed most interest. The present negotiations are the only ones being undertaken. A university spokesman estimated that up to 1,000 students could be taught on the campus, with the possibility of accommodation being shared with the Reading students. The Japanese university would be a separate entity.

Although financial pressure was the main motive behind the Reading move, the university does not acept criticisms that it is misusing the good name of the British university system for short-term financial expediency. If the two schemes prove successful, further lucrative deals between Japanese and British universities seem likely to follow. Simon Hadlington

\section{New virus lands in United States}

\section{Washington}

A SECOND human immunodeficiency virus (HIV) that causes AIDS (acquired immune deficiency syndrome) has turned up in North America. The new virus, HIV-2, was found in an AIDS patient living in New Jersey. Although epidemiologists have expected HIV-2 to show up in the United States, the Centers for Disease Control (CDC) in Atlanta do not believe that this first case signals a new epidemic.

HIV-2 was first found in West Africa by French researchers. The US patient, a West African who came to the United States in December 1987, was diagnosed as having cerebral toxoplasmosis, a secondary infection frequently found in AIDS patients. The patient had a negative enzyme immunoassay for antibodies to HIV-1. Because the patient came from West Africa, doctors at the University of Medicine and Dentistry of New Jersey (UMDNJ) where the patient was being treated decided to try an assay for HIV-2 being developed by Genetic Systems Corporation of Seattle, Washington. The HIV-2 immunoassay was positive. HIV-2 Western blot revealed the presence of core and envelope proteins. DNA ampli- fication with HIV-1 and HIV-2 specific probes indicated that the infection was caused by HIV-2.

The patient had a history of sexual contacts while in Africa, and had received injections while hospitalized there. HIV-2 way as HIV-1. Details of the case were reported in the CDC publication Morbidity and Mortality Weekly Report for 29 January (vol. 37, no. 3).

Stanley H. Weiss, formerly at the National Cancer Institute and now at UMDNJ, says this appears to be an isolated case. CDC, in collaboration with the Food and Drug Administration and other institutions, have now screened some 23,000 serum samples for the presence of HIV-2 antibodies. Of these, 35 (0.2 per cent) tested positive using Genetic Systems' enzyme immunoassay, but none of the 35 was confirmed using HIV-2 specific Western blot. All 35 positive samples came from a subgroup whose activities placed them at high risk for HIV-1 infection.

Weiss says the virus has been isolated from the infected patient, and is now being grown, so there will be sufficient quantities to sequence it. Joseph Palca is assumed to be transmitted in the same
CEST chief named London

THE man who will head Britain's latest effort to improve on its poor record of bringing science to the market-place was appointed last week. He is Dr Bob Whelan, the new chief executive of the Centre for

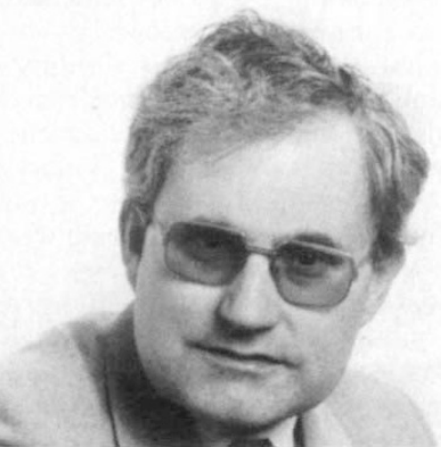

Dr Bob Whelan

Exploitation of Science and Technology (CEST), a body jointly funded by the government and a group of private companies. CEST's brief is to alert policy makers, industrialists and the research cmmunity to emerging areas of strategically important technologies (see Nature 330, 196; 1987).

Whelan, who is on indefinite secondment from his position as marketing director of PA Technology, part of a Britishowned international management and technical consultant group, expects to recruit a staff of a dozen, including economists and market analysts as well as scientists. One of the first priorities of CEST, which is based at the Manchester science park, will be to attract a large number of smaller technology-based businesses into its membership.

Whelan expects that once his staff have pinpointed a strategically important area of science, companies and academic institutions with relevant expertise will be identified and a detailed plan of action drawn up. Simon Hadlington

\section{Happy birthday, IUE}

Paris

THE International Ultraviolet Explorer Satellite (IUE) celebrated its tenth birthday in geosynchronous orbit over the Atlantic Ocean on 26 January. IUE, which is operated by the European Space Agency, the British Science and Engineering Research Council and the US National Aeronautics and Space Administration, is used by astronomers all over the world to study ultraviolet radiation blocked out by the Earth's upper atmosphere. With a large number of important observations under its belt, including the pinpointing of supernova SN1987A, observation of the comet IRAS and the remote galaxy Fairall-9, IUE remains one of the most productive astronomical telescopes, despite its small (40 $\mathrm{cm}$ ) diameter mirror. 